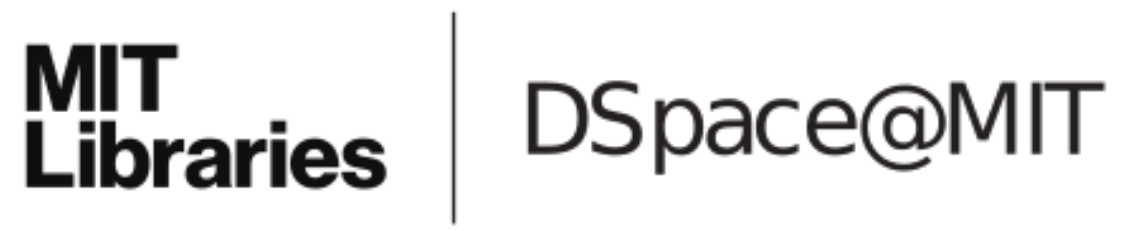

\author{
MIT Open Access Articles
}

Extending the Race between Education and Technology

The MIT Faculty has made this article openly available. Please share how this access benefits you. Your story matters.

Citation: Autor, David et al. "Extending the Race between Education and Technology." American Economic Association Papers and Proceedings, 110 (May 2020): 347-351 ( 2020 The Author(s)

As Published: 10.1257/PANDP.20201061

Publisher: American Economic Association

Persistent URL: https://hdl.handle.net/1721.1/130271

Version: Final published version: final published article, as it appeared in a journal, conference proceedings, or other formally published context

Terms of Use: Article is made available in accordance with the publisher's policy and may be subject to US copyright law. Please refer to the publisher's site for terms of use. 


\title{
THE RACE BETWEEN EDUCATION AND TECHNOLOGY REVISITED
}

\section{Extending the Race between Education and Technology}

\author{
By David Autor, Claudia Goldin, and Lawrence F. Katz*
}

A great economic divide has emerged between college-educated workers and those with less education. Ever since 1980, educational wage differentials have greatly expanded, and soaring income inequality has deeply marked the US economy. But that wasn't the way it always was in America.

The mid-twentieth century saw broadly shared prosperity, little change in wage inequality, and a relatively stable college wage premium. And the first half of the twentieth century, particularly the 1940s, saw actual declines in inequality and reductions in educational wage differentials. High school graduates in the early twentieth century were an elite group. But by 1940, the median youth had become a high school graduate. College going was next to take off. But, at some point, educational advances slowed.

Educational wage gains and overall wage and income inequality have closely followed changes in educational attainment against a backdrop of increased relative demand for more-educated workers from skill-biased technological change (SBTC). The implicit framework is one of a race between education and technology (RBET). The notion was first expounded by Tinbergen (1974) and later built on and applied to the US case

\footnotetext{
${ }^{\ddagger}$ Discussants: John Michael Van Reenen, Massachusetts Institute of Technology; Sandra E. Black, Columbia University; Chad Jones, Stanford University; Nicole Fortin, University of British Columbia.

*Autor: Department of Economics, Massachusetts Institute of Technology (email: dautor@mit.edu); Goldin: Department of Economics, Harvard University (email: cgoldin@harvard.edu); Katz: Department of Economics, Harvard University (email: 1katz@harvard.edu). We are grateful to Alice Wu for research assistance beyond the call of duty and to Harvard University for research support.

${ }^{\dagger}$ Go to https://doi.org/10.1257/pandp.20201061 to visit the article page for additional materials and author disclosure statement $(\mathrm{s})$.
}

by Katz and Murphy (1992), Goldin and Katz (2008), and Autor (2014), among others.

The RBET framework, according to Goldin and Katz (2008), neatly explains changes in US educational wage differentials across the twentieth century. The idea is that there is secular growth in the demand for more-educated workers from SBTC and there is rapid, but variable, growth of the relative supply of more-educated workers. An acceleration in relative supply growth from the high school movement reduced the high school wage premium in the first half of the twentieth century. Fast educational growth kept skill differentials in check during the mid-twentieth century. But from 1980 to 2005, a slowdown in relative education supply growth contributed to a soaring college wage premium.

But there's more to US history. What occurred in the most recent 15 years, and what happened during the industrially revolutionary nineteenth century? We extend the RBET for the last 200 years to assess its strengths and limitations.

\section{Long-Run Changes in US Educational Wage Differentials}

We have undertaken the Herculean task of mapping out US educational wage differentials from 1825 to 2017 . Figure 1 plots the evolution of these wage differentials.

We combine data from the Iowa State Census of 1915 (Goldin and Katz 2010), the first representative microsample with educational attainment and earnings, with more traditional US Census and March Current Population Survey (CPS) microsamples (Flood et al. 2018). To expand the series before 1914, we use occupational wage differentials and compare the earnings of those doing clerical work (a typical high school position) to the earnings of those doing production work (more typical of the less educated). For the earliest period shown, 1825 to 


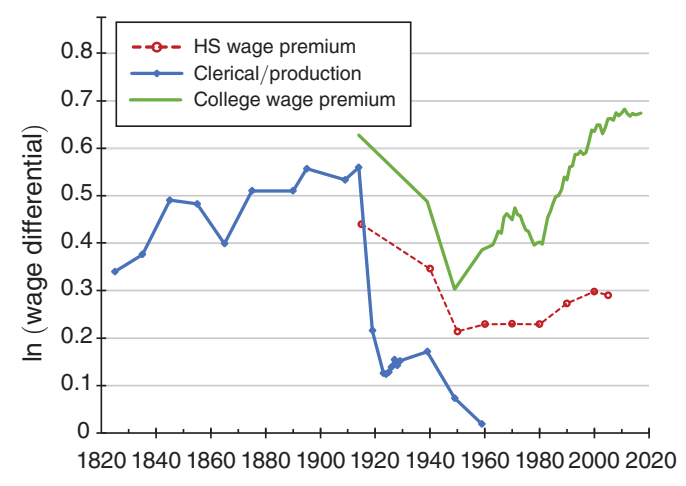

Figure 1. Educational and Occupational Wage DiFFERENTIALS: 1825 TO 2017

Notes: Clerical/production worker series for 1825 to 1875 is based on Katz and Margo (2014, table 1.5), and that for 1890 to 1959 is from Goldin and Katz (2008, table 2.2). High school wage premium series is from Goldin and Katz (2008, table D.1). College wage premium series from Goldin and Katz (2008, table 8.2) updated to 2017. See the online Appendix.

1875 , data on clerical and production workers are obtained from civilian hires of the US military (Katz and Margo 2014). For 1890 to 1959, various series on the wage of clerks to production workers are used.

The long-term series on occupational wage differentials show rising education wage gaps across the nineteenth and early twentieth centuries, suggesting increased demand for more-educated workers with the emergence of large-scale enterprises but modest supply growth due to a lack of access to high school. White-collar workers were a noncompeting group through the early twentieth century. Rising educational wage differentials characterized the period from the 1820 s to 1914 , not unlike that in more recent history.

The high school movement, starting around 1910 , then produced a large decline in the high school wage premium from 1914 to 1960 . The college wage premium also narrowed from 1914 to 1950 . But then, in a real roller coaster ride, the college wage premium rebounded in the 1950s and 1960s, narrowed in the 1970s, and then soared post-1980. The college wage premium today exceeds its high level of 1914.

The long-run increase in educational wage differentials has occurred despite large increases in the supply of more-educated workers. These large educational advances are illustrated in

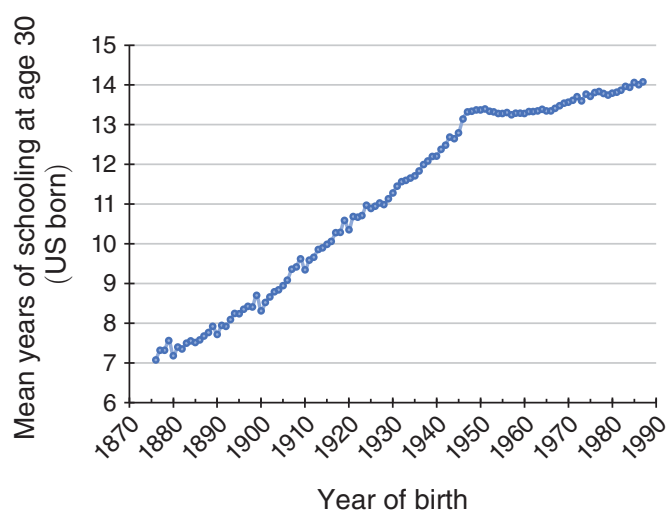

Figure 2. Mean Years of Schooling at Age 30 For the US Born, 1876 TO 1987 BIRTH COHORTS

Notes: US Census IPUMS data from 1940 to 2000 and CPS Merged Outgoing Rotation Groups (MORG) data from 2005 to 2018. The figure updates Goldin and Katz (2007, figure 7). See the online Appendix.

Figure 2, which gives the schooling attainment of each US birth cohort (1876 to 1987), measured at age 30 .

The rise of mass secondary schooling in the first part of the twentieth century and the development of a flexible system of higher education led to enormous increases in years of education (Goldin and Katz 2008). Educational attainment rose rapidly for cohorts born between 1876 and 1951. Mean years of schooling increased by 5.9 years (from 7.3 to 13.2 years), or by 0.79 years per decade. Each successive generation of Americans had two more years of schooling than its parents.

Then the series hit a plateau, with educational attainment barely changing for cohorts born from 1951 to 1966. It began to rise again but at a slower pace than previously. Educational attainment for the 1951 to 1987 birth cohorts rose by 1.1 years up to a level of 14.3 years, a rate of increase of just 0.29 years per decade.

How much did this slowdown in the growth of educational attainment contribute to the recent rise in the college wage premium?

\section{The Race between Education and Technology: 1914 to 2017}

We follow Katz and Murphy (1992), Goldin and Katz (2008), and Autor, Katz, and Kearney 
(2008) in modeling changes in educational wage differentials as a race between the supply of skills (driven by changes in the educational attainment of the work force) and demand for skills (driven by SBTC). We apply this approach to the evolution of the college wage premium from 1914 to 2017.

Our framework postulates a CES production function for aggregate output $Q$ with two factors, skilled workers $(S)$ and unskilled workers $(U)$ who perform imperfectly substitutable tasks:

$$
Q_{t}=\left[\alpha_{t}\left(a_{t} L_{S_{t}}\right)^{\rho}+\left(1-\alpha_{t}\right)\left(b_{t} L_{U_{t}}\right)^{\rho}\right]^{\frac{1}{\rho}},
$$

where $L_{S}$ and $L_{U_{t}}$ are the quantities of skilled labor and unskilled labor employed in period $t, a_{t}$ and $b_{t}$ represent skilled and unskilled labor augmenting technological change, and $\alpha_{t}$ is a time-varying technology parameter indexing the share of work activities allocated to skilled labor. The production function parameter $\rho$ is related to $\sigma_{S U}$, the aggregate elasticity of substitution between skilled and unskilled labor, such that $\sigma_{S U}=1 /(1-\rho)$. Skill-neutral technological improvements raise $a_{t}$ and $b_{t}$ by the same proportion. Increases in $\left(a_{t} / b_{t}\right)$ or in $\alpha_{t}$ both represent SBTC. We focus on the college and high school divide so that skilled workers $(S)$ are "college equivalents" (college graduates plus half of those with some college) and unskilled workers $(U)$ are "high school equivalents" (those with 12 or fewer years of schooling and half of those with some college).

Under the assumption that college and high school equivalents are paid their marginal products, we can use equation (1) to solve for the ratio of the marginal products of the two skill groups, yielding a relationship between relative wages and relative skill supplies in $t$ given by

$$
\ln \left(\frac{w_{S_{t}}}{w_{U_{t}}}\right)=\frac{1}{\sigma_{S U}}\left[D_{t}-\ln \left(\frac{L_{S_{t}}}{L_{U_{t}}}\right)\right],
$$

where $D_{t}$, measured in $\log$ quantity units, depends on the SBTC parameters and indexes relative demand shifts favoring college equivalents. The terms in brackets in equation (2) show how the evolution of the college wage premium depends on a race between the relative demand for and supply of skills. The aggregate elasticity of substitution between college and high school equivalents $\left(\sigma_{S U}\right)$ determines how much changes in skill supplies affect the college wage premium.

How important are supply and demand shifts for the evolution of the college wage premium since 1914, as shown in Figure 1? We estimate equation (2) for the US college wage premium on the relative supply of college equivalents to high school equivalents for 1914 to 2017 with demand shifts given by smooth time trends and, in some specifications, an allowance for institutional wage setting in the 1940s. The estimates are presented in online Appendix Table A1.

The core findings are of a substantial positive secular trend in the relative demand for college workers and a strong negative impact of increases in the relative supply of college workers on the college wage premium. A 10 percent increase in the relative supply of college equivalents reduces the college wage premium by around 6 percent. The implication is that $\sigma_{S U}$ is approximately 1.62 (using the estimate in column 2 of Table A1), similar to other estimates in the literature, typically in the 1 to 2.5 range. Figure A1 plots the actual college wage premium and the predicted college wage premium based on column 2 of Table A1.

Figure A1 reveals that a model with smooth secular relative demand trends favoring college workers, together with fluctuations in relative supply, does a fine job of fitting the long-run path of the college wage premium. There are exceptions to this stark representation. These include the large decline in the 1940s (likely driven by strong unions, tight labor markets, and government wage pressures), continued decline in the late 1970s (likely due to union wage gains and minimum wage increases), and sharp rise in the early 1980s. But, by and large, the RBET framework performs well.

The model's results do divulge a puzzling slowdown in the trend demand growth for college equivalents starting in the early 1990s. Rapid and disruptive technological change from computerization, robots, and artificial intelligence is not to be found-though the impact of these technologies may not be well captured by this two-factor setup. The large rise in the college wage premium since 1980 is driven more by slower relative supply growth than by an acceleration in SBTC. A comparison of the two periods, 1979 to 2017 and 1939 to 1979, illustrates the point (as seen in Table A2). 
The log college wage premium increased by 0.274 from 1979 to 2017 (from 0.4 to 0.674, or by 0.072 per decade). Compare that to the change from 1939 to 1979 when the premium declined by 0.088 (by 0.022 per decade). The rate of growth of the log relative supply of college equivalents was 0.31 per decade (or 3.1 percent per annum) from 1939 to 1979 . But it decreased to 0.213 per decade $(2.13$ percent per annum) from 1979 to 2017.

The slowdown in relative supply growth accounts for 62 percent $(0.058)$ of the 0.094 per decade increase in the growth rate of the college wage premium post-1979 relative to 1939 to 1979 , under the assumption that $\sigma_{S U}=1.62$. The implied acceleration in the growth of $\log$ relative demand for college equivalents of 0.058 per decade explains 38 percent $(0.036)$ of the surge in the college wage premium after 1970, as compared with the pattern of modest decline in the mid-twentieth century.

A key question is why the secular trend terms in the estimated version of equation (2) should be interpreted as reflecting relative demand shifts favoring college graduates from SBTC. For example, the implied faster relative demand growth post-1979 as compared with 1939 to 1979 could partially reflect institutional factors omitted from the framework, such as stronger unions and more egalitarian wage norms in the earlier period.

In the late twentieth century these eroded with declining union density, a decreased real minimum wage, and a more market-based wage setting. But much evidence does favor a primary role for SBTC in the trend terms. Large within-industry and within-firm shifts to more educated workers in the face of rising educational wage differentials strongly suggest SBTC (Katz and Murphy 1992).

\section{Wage Inequality since 1980}

How much of the overall rise in wage inequality since 1980 can be attributed to the large increase in educational wage differentials? We follow Goldin and Katz (2007) and provide an intuitive answer using data from the 1979 to 2018 CPS MORG samples (National Bureau of Economic Research 2019).

We first estimate modified cross-section Mincerian human capital earnings regressions with log hourly wages as the dependent variable. We include a linear spline in years of schooling (with break points after 12 and 16 years); a quartic in potential labor market experience, race, region, gender, and year dummies; and interactions of gender and the experience quartic. The linear spline in education allows the "returns" to an additional year of schooling to differ for $\mathrm{K}-12$, college, and post-bachelor's degree schooling. The estimation is done for 1980 (1979 to 1981 pooled), 2000 (1999 to 2001), and 2017 (2016 to 2018).

We examine the role of changing education returns from 1980 to 2017 by first imposing the 2017 returns to schooling on 1980, adjusting individual wages in 1980 . We then compare the distributions of actual and adjusted wages in 1980 to determine what wage inequality would have been with education returns at 2017 levels. Wages in 2017 are then adjusted by imposing the 1980 education returns. We use the average of the two simulations. We repeat for 1980 to 2000 and for 2000 to 2017. The results are summarized in Table A3.

The earnings regressions for 1980, 2000, and 2017 imply that the returns to post-secondary schooling greatly increased to 2017 and simultaneously convexified. Returns to a year of K-12 schooling show little change since 1980. But returns to a year of college rose by $6.5 \log$ points, from 0.076 in 1980 , to 0.126 in 2000 , to 0.141 in 2017. The returns to a year of post-college education (graduate and professional) rose by a whopping $10.9 \log$ points, from 0.067 in 1980 , to 0.131 in 2000, and to 0.176 in 2017.

Our simulations imply that the increase in post-secondary schooling returns increased the variance of log hourly wages by 0.070 from 1980 to 2017 . Thus, 57 percent of the increase in variance (of 0.123 , from 0.250 in 1980 to 0.373 in 2017) can be accounted for by increased schooling returns. The rise in returns to schooling similarly accounts for 57 percent of the increase in the 90-10 log hourly wage differential of 0.305 over the full period.

Wage inequality increased at about the same rate from 1980 to 2000 as from 2000 to 2017. But the college wage premium increased far more rapidly in the first period than in the second. The rise in the returns to college education explains a far larger share of the increased log hourly wage variance from 1980 to 2000 than it does from 2000 to 2017, accounting for 75 percent in the first period but just 38 percent more recently. 
The canonical two-skill model of the RBET explains the lion's share of the enormous increase in wage inequality from 1980 to 2000 , when the slowdown in the growth of the relative supply of college workers produced a sharp rise in the college wage premium.

But most of the recent rise in wage inequality has occurred within, rather than between, education groups. The largest part of increased wage variance in the twenty-first century comes from rising inequality among college graduates, with almost no change in wage inequality since 2000 for noncollege workers.

Comprehending rising wage inequality in the 2000s requires a better understanding of growing wage inequality among college graduates and of the stagnant earnings of middle-wage workers. The RBET framework remains relevant in the twenty-first century but needs some tweaks.

\section{REFERENCES}

Autor, David H. 2014. "Skills, Education, and the Rise of Earnings Inequality among the 'Other 99 Percent." Science 344 (6186): 843-51.

Autor, David H., Lawrence F. Katz, and Melissa S. Kearney. 2008. "Trends in U.S. Wage Inequality: Revising the Revisionists." Review of Economics and Statistics 90 (2): 300-323.

Flood, Sarah, Miriam King, Renae Rodgers, Steven Ruggles, and J. Robert Warren. 2018. "March Current Population Surveys, 1964 to 2018." Integrated Public Use Microdata Series Current Population Survey: Version 6.0. Minneapolis, MN: IPUMS. https://doi. org/10.18128/D030.V6.0.

Goldin, Claudia, and Lawrence F. Katz. 2007. "Long-Run Changes in the Wage Structure: Narrowing, Widening, Polarizing." Brookings Papers on Economic Activity 47 (2): 135-65.

Goldin, Claudia, and Lawrence F. Katz. 2008. The Race between Education and Technology. Cambridge, MA: Harvard University Press.

Goldin, Claudia, and Lawrence F. Katz. 2010. The 1915 Iowa State Census Project. Ann Arbor, MI: Inter-university Consortium for Political and Social Research. https://doi.org/10.3886/ ICPSR28501.v1

Katz, Lawrence F., and Robert A. Margo. 2014. "Technical Change and the Relative Demand for Skilled Labor: The United States in Historical Perspective." In Human Capital in History: The American Record, edited by Leah Platt Boustan, Carola Frydman, and Robert A. Margo, 15-57. Chicago: University of Chicago Press.

Katz, Lawrence F., and Kevin M. Murphy. 1992. "Changes in Relative Wages, 1963-1987: Supply and Demand Factors." Quarterly Journal of Economics 107 (1): 35-78.

National Bureau of Economic Research. 2019. "Current Population Survey (CPS) at the NBER.” https://data.nber.org/cps/.

Tinbergen, Jan. 1974. "Substitution of Graduate by Other Labor.” Kyklos 27 (2): 217-26. 